\title{
IDENTIFIKASI HORMON PEMACU TUMBUH EKSTRAK CAIRAN (SAP) Eucheuma cottonii
}

\author{
Identification of Growth Promoting Hormones in The Sap of \\ Eucheuma cottonii
}

\author{
Bakti Berlyanto Sedayu ${ }^{1 *}$, Jamal Basmal ${ }^{2}$, dan Bagus Sediadi Bagus Utomo ${ }^{2}$ \\ ${ }^{1}$ Loka Penelitian dan Pengembangan Mekanisasi Pengolahan Hasil Perikanan, KKP. \\ JI. Imogiri Barat KM 11.5 Jetis, Bantul, DI Yogyakarta 55781 \\ ${ }^{2}$ Balai Besar Penelitian dan Pengembangan Pengolahan Produk dan Bioteknologi Kelautan dan Perikanan, KKP. \\ Jl. K.S. Tubun Petamburan VI, Jakarta Pusat 10260 \\ * Korespondensi Penulis: bakti@kkp.go.id \\ Diterima: 28 Juli 2012, Disetujui: 26 Pebruari 2013
}

\begin{abstract}
ABSTRAK
Rumput laut telah lama digunakan sebagai bahan pupuk organik karena kaya akan kandungan hormon pemacu tumbuh (HPT) dan unsur hara lainnya yang dibutuhkan tanaman. Pada penelitian ini, diidentifikasi senyawa HPT yang terkandung dalam ekstrak cairan (sap) rumput laut Eucheuma cottonii menggunakan HPLC, selanjutnya dibandingkan dengan kandungan HPT pada pupuk rumput laut komersial (berdasarkan data sekunder hasil studi literatur). Hasil analisis menunjukkan bahwa sap E. cottonii mengandung giberelin yang terdiri dari gibberellic acid GA3 dan GA7 sebesar 128 dan 110 ppm, sitokinin yang terdiri dari zeatin dan kinetin sebesar 117 dan 73 ppm, dan auksin berupa Indole Acetic Acid (IAA) sebesar 160 ppm. Kandungan HPT sap E. cottonii ini lebih tinggi dibandingkan dengan HPT beberapa produk pupuk organik berbahan dasar rumput laut komersial. Hal ini menunjukkan bahwa E. cottonii memiliki potensi untuk dikembangkan menjadi bahan pemacu pertumbuhan tanaman dalam pembuatan pupuk organik. Namun demikian, hasil pemanfaatan sisa padatan (ampas) rumput laut yang telah di ambil sapnya menjadi Alkali Treated Cottonii (ATC) menunjukkan hasil kualitas yang lebih rendah.
\end{abstract}

KATA KUNCI: Eucheuma cottonii, hormon pemacu tumbuh (HPT), giberelin, sitokinin, auksin

\section{ABSTRACT}

Seaweeds have been used for years as organic fertilizer due to their high amount of Growth Promoting Hormones (GPH) and other nutrients required by plants. In this experiment, identification of GPH compounds in Eucheuma cottonii sap has been carried out using HPLC. The results were then compared with those of the commercial seaweed fertilizers (based on secondary data). The results showed that the sap of E. cottonii contained gibberellin i.e. gibberellic acid, GA3 and GA7 with the concentration of 128 and 110 ppm, cytokinin i.e. zeatin and kinetin of 117 and 73 ppm, and auxin i.e. indole acetic acid (IAA) of $160 \mathrm{ppm}$. In general, the sap of E. cottonii showed a higher amount of GPH than those of some commercial seaweed fertilizers, and it demonstrated a potential use of E. cottonii to be developed as a plant growth stimulant in organic fertilizer. Nevertheless, production of Alkali Treated Cottonii (ATC) using the sap extracted seaweed resulted a poorer quality.

KEYWORDS: Eucheuma cottonii, plant growth hormones, gibberellin, cytokinin, auxin

\section{PENDAHULUAN}

Pemanfaatan rumput laut, khususnya di Indonesia, hingga saat ini umumnya masih terbatas sebagai produk pangan dan produk semi-jadi seperti agar kertas, alkali treated cottonii (ATC), jelly-product, dan beberapa produk kosmetik. Penelitian-penelitian mengenai fungsi biologi dari ekstrak rumput laut sebagai pemacu pertumbuhan tanaman guna meningkatkan hasil panen masih belum banyak dilakukan. Di negara-negara lain seperti di Australia, Perancis, Inggris, India, Jepang, New Zealand, Skotlandia, Spanyol, dan Amerika rumput laut telah lama diketahui sebagai pupuk tanaman pertanian (Zahid, 1999). Ekstrak rumput laut telah banyak dipasarkan sebagai bahan tambahan pada pupuk tanaman yang manfaat serta keuntungan penggunaannya telah banyak dilaporkan (Fornes et 
al., 2002; Padhi \& Swain, 2006; Sivansankari et al., 2006; Prithiviraj, 2009).

Dalam perkembangannya, pemanfataan rumput laut pada pertanian modern telah banyak diinvestigasi oleh banyak peneliti. Kini berbagai jenis atau bentuk preparasi rumput laut seperti Liquid Seaweed Fertilizer (LSF), Seaweed Liquid Fertilizer (SLF), Liquid Fertilizer (LF), dan chopped powered algal manure telah umum digunakan di berbagai negara, dan keseluruhannya telah dilaporkan menghasilkan dampak yang menguntungkan terhadap bermacam tanaman seperti serealia, kacang-kacangan, sayuran dan tanaman bunga (Chapman \& Chapman, 1980; Kubo, 1989; Zahid, 1999; dan Padhi \& Swain, 2006). Beberapa pupuk organik komersial berbahan dasar rumput laut yang kini telah dikenal luas di pasaran internasional diantaranya adalah Maxicrop (Amerika Serikat), Kelpar (Afrika Selatan), Algifer (Inggris), Boost (AS), Seaweed Extract dan lainnya. Sedangkan bahan baku yang digunakan untuk pupuk organik komersial diantaranya berasal dari jenis Ascophyllum nodosum, Macrocystis pyrifera, Ecklonia maxima, Durvillea potatorum, dan Durvillea antartica (Prithiviraj, 2009).

Selain kaya akan kandungan mineral, nutrien anorganik, dan senyawa organik yang dapat meningkatkan pertumbuhan tanaman, rumput laut juga diketahui memiliki kandungan hormon pemacu tumbuh (HPT) (Mooney \& Van Staden, 1985), di antaranya sitokinin (Smith \& Van Staden, 1984), auksin (Abe et al., 1972), dan giberelin (Sekar et al., 1995). Beberapa produk pupuk organik berbahan dasar rumput laut Ascophyllum yang telah dikenal luas di pasaran internasional yang secara umum diaplikasikan sebagai stimulan pertumbuhan tanaman di antaranya adalah Acadian, Agri-Gro ultra, AgroKelp, Alg-A-Mic dan BioGenesis, yang berbahan dasar rumput laut Durvillea adalah Profert dan Seasol; dari rumput laut Ecklonia adalah Kelpak; dan yang tidak menyebutkan jenis rumput laut yang dipakai adalah Fartum, Sea winner dan seanure (Prithiviraj, 2009).

Penelitian ini merupakan kegiatan pendahuluan untuk meningkatkan nilai tambah rumput laut dengan cara memanfaatkannya sebagai bahan dasar pembuatan pupuk organik. Pada penelitian ini, diidentifikasi keberadaan HPT yang merupakan unsur mikro sangat penting bagi pertumbuhan tanaman, yang meliputi: auksin, giberelin, dan sitokinin. Rumput laut yang digunakan adalah jenis alga merah, Eucheuma cottonii, yang merupakan rumput laut paling banyak dibudidayakan di perairan Indonesia dan memiliki kandungan cairan sangat tinggi, yaitu sekitar 90\% setelah pemanenan (Sedayu et al., 2011). Aplikasi hormon pemacu tumbuh pada pupuk ditujukan untuk merangsang pertumbuhan pada tanaman sehingga tanaman dapat tumbuh, berbuah atau berbunga lebih besar, lebih banyak dan lebih cepat, sehingga diharapkan akan mampu meningkatkan hasil produksi tanaman pertanian dan hortikultura.

\section{BAHAN DAN METODE}

Rumput laut Eucheuma cottonii segar yang diperoleh dari perairan Sumenep-Madura, dengan umur panen berkisar 20-25 hari dihancurkan menggunakan blender dan dimasukkan ke dalam kantong kain belacu. Setelah itu rumput laut diperas secara manual hingga ekstrak rumput laut keluar dari kain lalu ditampung dalam wadah penampung. Ekstrak rumput laut diberikan pengawet formalin $2 \%$. Selanjutnya ekstrak dibawa ke laboratorium untuk dianalisis kandungan hormon pemacu tumbuhnya, meliputi: auksin, giberelin, dan sitokinin menggunakan HPLC.

Preparasi dan analisis HPT dilakukan dengan modifikasi metode Linskens \& Jackson (1987) menggunakan HPLC Waters 2487 dan detektor UVVis. Hasil kuantitatif HPT dihitung berdasarkan perbandingan luas area grafik senyawa HPT dengan standarnya.

\section{Preparasi dan Analisis Giberelin}

Sampel ekstrak rumput laut seberat $2 \mathrm{~g}$ dimasukkan ke dalam corong pisah kemudian diekstrak dengan etil asetat $3 \times 10 \mathrm{ml}$, setelah itu dilewatkan dalam kolom resin silika. Hasil elusi dievaporasi menggunakan vacuum evaporator pada suhu $55^{\circ} \mathrm{C}$ kemudian sampel dikeringkan menggunakan freeze dryer. Sampel kering dilarutkan dalam $10 \mathrm{ml}$ metanol 80\% kemudian disaring menggunakan milliphore, setelah itu dianalisis mengunakan HPLC Waters 2487. Kolom HPLC yang digunakan yaitu C-18 dengan fase gerak metanol. Senyawa giberelin dibaca menggunakan detektor UVVis pada panjang gelombang $254 \mathrm{~nm}$.

\section{Preparasi dan Analisis Auksin dan Sitokinin}

Sampel ekstrak rumput laut seberat $2 \mathrm{~g}$ dimasukkan ke dalam corong pisah kemudian diekstrak dengan metanol 3×10 ml. Hasil ekstraksi dikeringkan menggunakan freeze dryer. Sampel kering dilarutkan dalam $30 \%$ asam asetat dalam asetonitril $23 \mathrm{ml}$. Setelah itu disentrifuse pada kecepatan putaran $4000 \mathrm{rpm}$ selama 30 menit. Supernatan disaring dengan miliphore kemudian dianalisis dengan menggunakan HPLC. Hasil analisis jumlah kandungan HPT ekstrak E.cottonii yang didapatkan kemudian dibandingkan dengan jumlah kandungan HPT yang terdapat dalam pupuk organik komersial (data sekunder). 


\section{Pemanfaatan sisa padatan rumput laut sebagai Alkali Treated Cottonii (ATC)}

Rumput laut sisa (ampas) yang telah diambil cairannya kemudian dikeringkan matahari (dijemur), lalu diolah menjadi alkali treated cottonii (ATC) dengan ekstraksi menggunakan larutan $\mathrm{KOH} 8 \%$ selama 3 jam pada suhu $75^{\circ} \mathrm{C}$. ATC yang dihasilkan diuji kekuatan gelnya (gel strength) (Marine Colloid, 1978).

\section{HASIL DAN BAHASAN}

Ekstrak cairan (sap) rumput laut E.cottonii yang dihasilkan sebesar $54 \%(\mathrm{v} / \mathrm{w})$. Hasil analisis sap tersebut menggunakan HPLC menunjukkan hasil positif akan keberadaan kandungan hormon pemacu tumbuh tanaman yaitu giberelin, sitokinin, dan auksin. Senyawa-senyawa tersebut diketahui berperan dalam pertumbuhan tanaman. Senyawa auksin berperan dalam proses fisiologi tumbuhan, seperti pertumbuhan, pembelahan, dan diferensiasi sel, serta sintesis protein. Giberelin diketahui mempengaruhi dormansi puncak, pertumbuhan kambium, geotropisme, absisi dan partenokarpi, efektif meningkatkan sel buah, perangsangan pertumbuhan antar buku sehingga tumbuhan tidak kerdil (Gardner et al., 1991). Sedangkan sitokinin sangat berperan dalam pembelahan sel yang menyebabkan respon tumbuhan terhadap pertumbuhan tanaman, pertumbuhan buah, dan germinasi kecambah (Wu \& Lin, 2000).

\section{Identifikasi Hormon Pemacu Tumbuh}

\section{Giberelin}

Giberelin yang terkandung dalam sap E.cottonii terdiri dari GA3 dan GA7 dengan konsentrasi sebesar 128 dan 110 ppm (Gambar 1). Giberelin merupakan senyawa organik yang berperan dalam proses perkecambahan karena dapat mengaktifkan reaksi enzimatik di dalam benih sehingga metabolisme sel meningkat (Bey et al., 2005). Struktur kimia giberelin dapat dilihat pada Gambar 2.

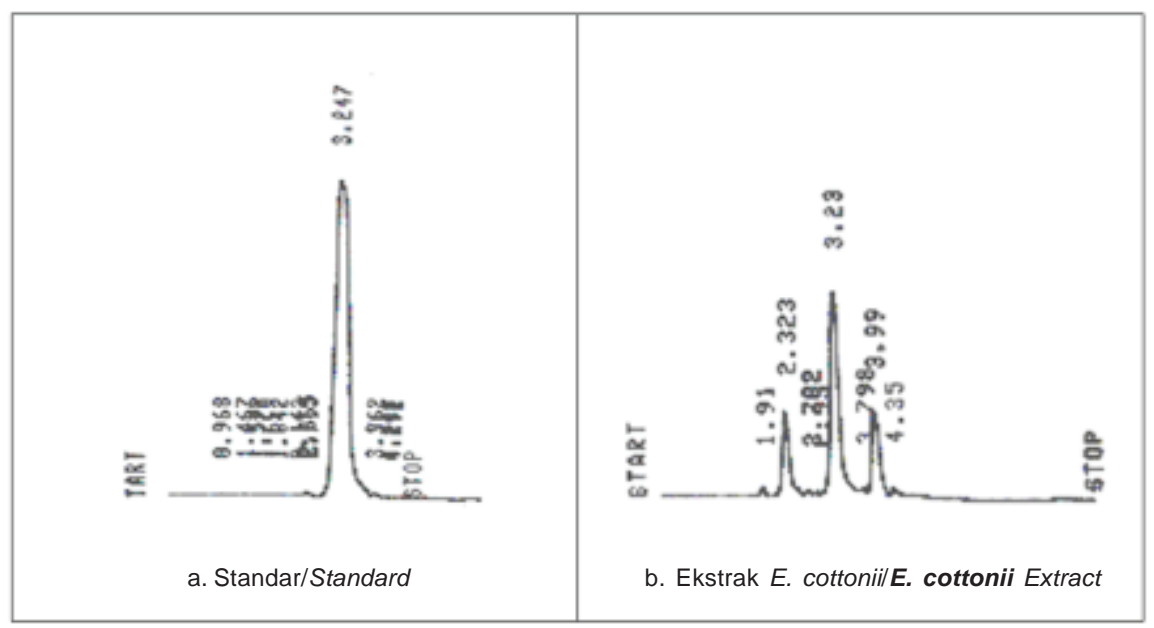

Gambar 1. Hasil uji analisis giberelin pada sap E.cottonii menggunakan HPLC. Figure 1. The result of giberelin analysis of the sap of E.cottonii using HPLC.

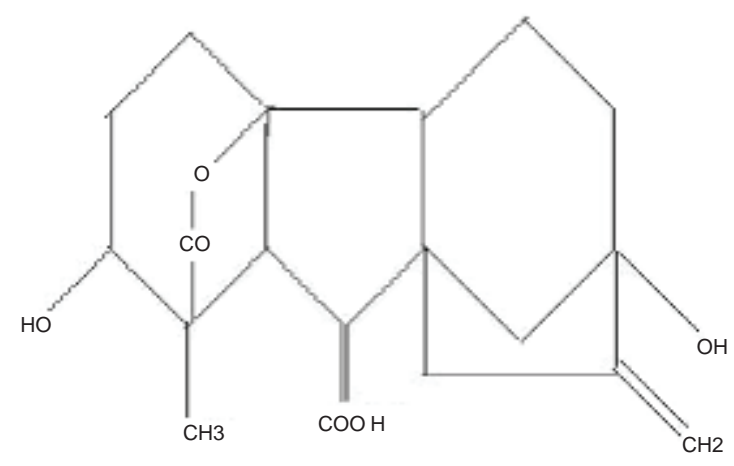

Gambar 2. Struktur molekuler giberelin.

Figure 2. Molecular structure of giberelin (Anon., 2008). 
Crouch \& van Staden (1992) mengidentifikasi konsentrasi giberelin yang terdapat dalam pupuk organik komersial yang berbahan dasar rumput laut, diantaranya adalah: Maxicrop sebesar 0,03-18,4 ppm, Kelpar 66 sebesar 0,05 ppm, dan Seaweed Extract sebesar 53,6-149 ppm. Dibandingkan dengan jumlah konsentrasi yang terkandung dalam pupuk organik rumput laut komersial tersebut, maka sap E.cottonii menunjukkan jumlah kandungan giberelin yang jauh lebih tinggi. Namun demikian, Williams et al. (1976) mengidentifikasikan bahwa rendahnya kandungan giberelin pada produk pupuk organik komersial dapat disebabkan karena terdegradasinya senyawa tersebut pada saat proses pengolahan/produksi, dan juga perbedaan jumlah kandungan giberelin tergantung dari proses yang digunakan pada produksi komersial.

\section{Auksin}

Senyawa auksin pada jaringan tumbuhan memiliki lebih dari satu bentuk senyawa kimia. Namun demikian, senyawa aktif yang dipercaya berperan dalam mengatur pertumbuhan tanaman termasuk pembentukan buah, dan pembentukan akar adalah senyawa indole-3-acetic acid (IAA) (Thirmann \& Scoog, 1940) (Gambar 3). Hasil analisis auksin (IAA) ekstrak cairan E.cottonii didapatkan konsentrasi sebesar 116 ppm. (Gambar 4). Jumlah ini lebih besar jika dibandingkan dengan konsentrasi auksin pada pupuk organik asal Amerika Serikat, Maxicrop. Standerson et al. (1987) menganalisis senyawa IAA pada Maxicrop dan mengestimasi kandungannya sebesar 6,63 ppm.

Auksin atau senyawa sejenis auksin (auxin-like compounds) diketahui terdapat secara alami pada beberapa alga laut (Schiewer \& Libbert, 1965; Sumera \& Cajipe, 1981). Penelitian penting awal dilakukan oleh Van Overbeek (1940) yang mendeteksi dugaan keberadaan indole-3-acetic acid (IAA) pada beberapa alga laut, khususnya Nereocystis. Selanjutnya, dengan menggunakan GC-MS, IAA juga terdeteksi pada Caulerpa paspaloides, S.heterophylum, dan alga lainnya (Abe et al., 1972 dan 1974; Jacobs et al., 1985). Sedangkan, Crouch \& Van Staden (1993) mengidentifikasi adanya senyawa IAA, Indole-3carboxylic acid (ICA), N'N-dimethyltryptamine, indole-

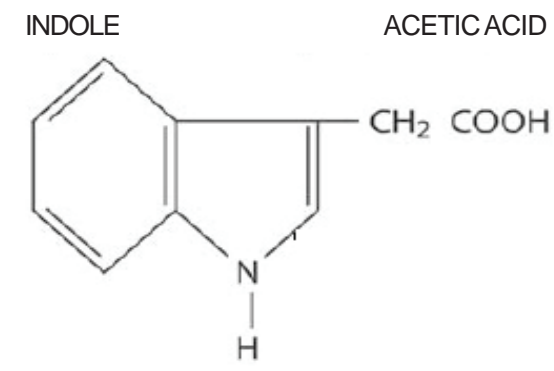

Gambar 3. Struktur molekuler IAA.

Figure 3. Molecular structure of IAA (Anon., 2008).

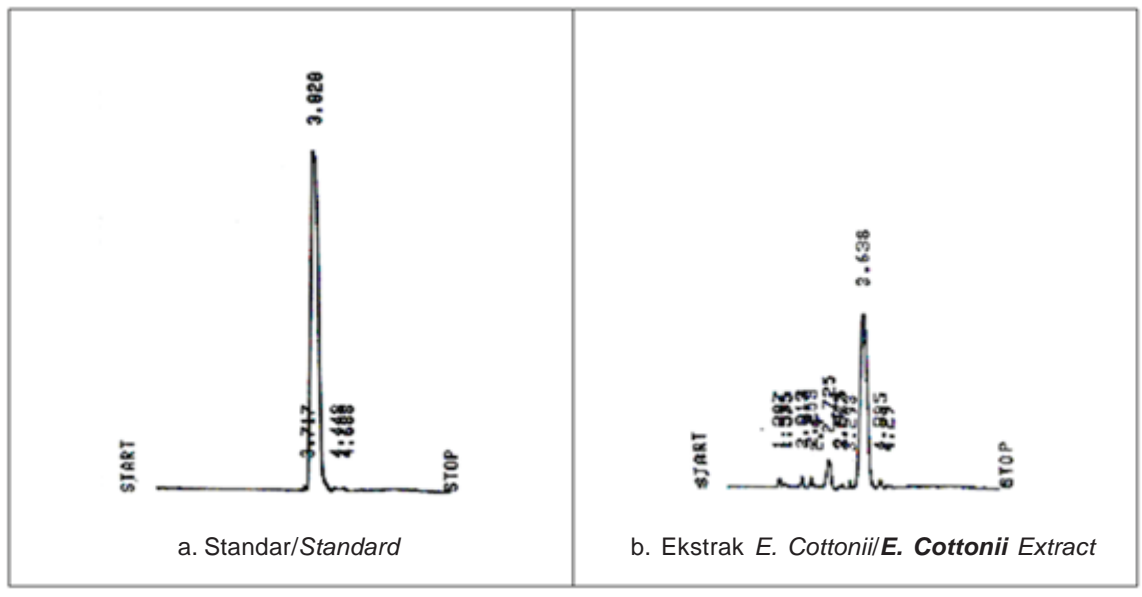

Gambar 4. Hasil analisis senyawa auksin pada ekstrak cairan E.cottonii. Figure 4. The result of auxin analysis of the sap of E. cottonii using HPLC. 
3-aldehyde (IAId) dan iso-indile,1,3-dione (N-hydroxyethylphthalimide) pada produk Kelpak.

Perbedaan kandungan auksin dalam ekstrak rumput laut dapat disebabkan oleh jenis rumput laut yang digunakan sebagai bahan pupuk organik. Maxicrop, yang berbahan dasar rumput laut Ascophylum nodossum (alga cokelat) memiliki kandungan auksin yang lebih rendah jika dibandingkan E.cottonii. Hal ini dijelaskan oleh Han (2006) yang mengidentifikasi adanya kandungan IAA dari 16 jenis spesies alga laut yang ada di perairan China. Hasilnya didapatkan bahwa senyawa IAA terdapat pada seluruh alga laut yang diamatinya dengan distribusi konsentrasi yang besar yaitu 0,001-0,11 ppm berat basah. Konsentrasi IAA terendah ditemukan pada alga coklat (Phaeophyceae) sedangkan yang tertingi pada alga merah (Rhodophyceae) sebesar 0,11 ppm (berat basah) yaitu pada Polysiphonia urceolata.

\section{Sitokinin}

Sitokinin pada tumbuhan dapat berasal dari dua sumber, yaitu yang berasal dari tumbuhan itu sendiri (endogenous cytokinin) yang berperan penting dalam pertumbuhan tanaman terutama untuk mendukung pembelahan sel (Taiz \& Zeiger, 1991), dan exogenous cytokinin yang sengaja diberikan ke tanaman yang telah diketahui dapat meningkatkan ketahanan tanaman pada keadaan lingkungan yang buruk (Beckett \& Van Staden, 1991).

Menurut Lin et al (1996) sitokinin yang terkandung dalam ekstrak rumput laut kemungkinan berasal dari sintesis de novo atau dari degradasi tRNA. Pendeteksian dengan menggunakan HPLC dan detektor UV-Vis spektrofotometer pada penelitian ini memberikan hasil sitokinin secara kuantitatif dari senyawa zeatin dan kinetin sebesar masing-masing 117 dan 73 ppm (Gambar 5).

Pada beberapa produk pupuk rumput laut komersial didapatkan jumlah kandungan sitokinin sebagai berikut: Maxicrop sebesar 25-200 ppm, Algifer 10-50 ppm, Boost sebesar 100 ppm, Kelpar 66 sebesar 15150 ppm, dan Seaweed Extract sebesar 125-210,8 ppm (Crouch \& van Staden, 1993). Berdasarkan data tersebut, terlihat bahwa jumlah sitokinin yang terkandung dalam ekstrak cair E.cottonii berada dalam kisaran yang sama dengan yang terdapat pada pupuk komersial berbahan dasar rumput laut, bahkan memiliki konsentrasi yang lebih tinggi dibandingkan dengan Algifer.

Perbedaan kandungan sitokinin pada ekstrak rumput laut dipengaruhi oleh beberapa faktor, di antaranya oleh faktor musim, fase perkembangan rumput laut (Mooney \& van Staden, 1984 ${ }^{\mathrm{b}}$ ), dan metode pendeteksiannya (Brenner, 1981). Selain itu, jenis rumput laut juga mempengaruhi keberadaan sitokinin dalam ekstrak cair rumput laut. Hal ini juga diperkuat oleh penelitian Lin et al. (1996) yang mengidentifikasi adanya kandungan sitokinin pada beberapa jenis alga hijau yaitu Ulva pertusa, Enteromopha compressa, dan Monostroma sp. yang berkisar antara 0,02-0,045 ppm. Jumlah ini jauh lebih rendah jika dibandingkan hasil yang diperoleh dari ekstrak E.cottonii (alga merah).

Pakar dalam bidang biologi tumbuhan menemukan bahwa sitokinin dapat meningkatkan pembelahan, pertumbuhan dan perkembangan kultur sel tanaman,

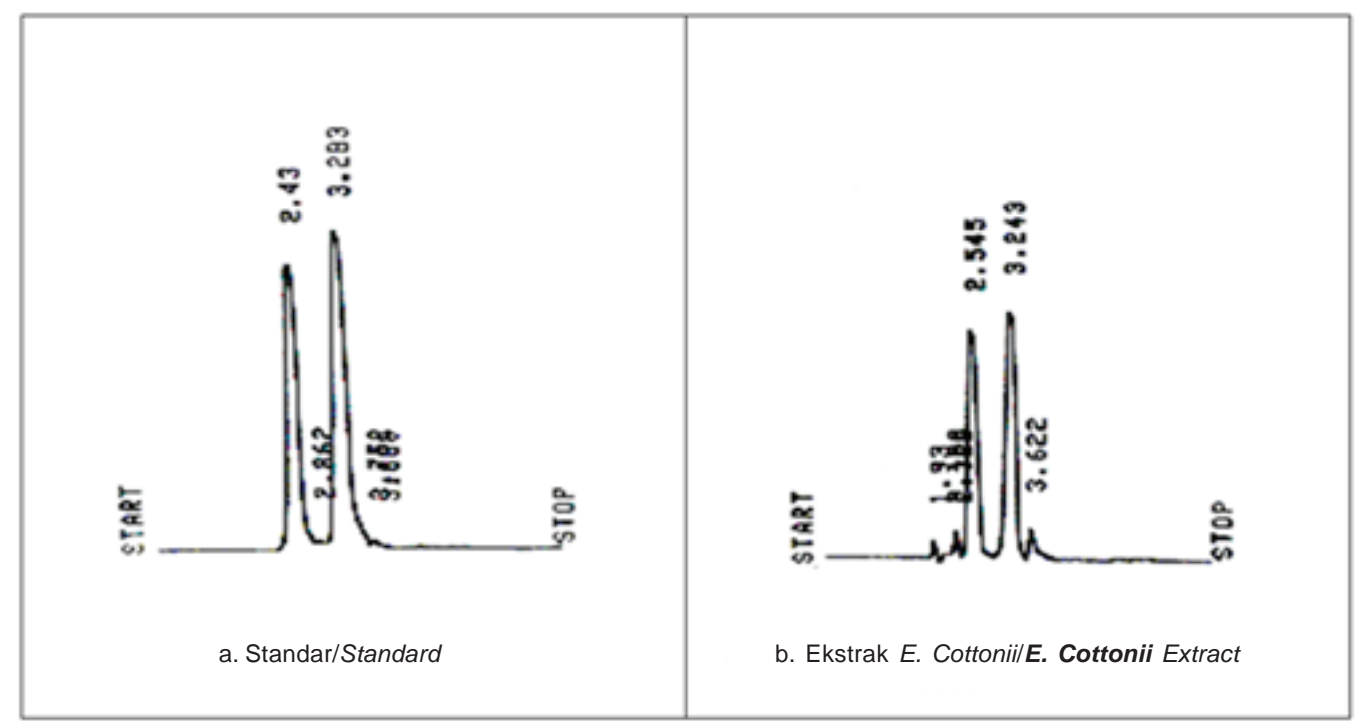

Gambar 5. Hasil analisis sitokinin pada sap E.cottonii menggunakan HPLC. Figure 5. The result of cytokinin analysis of the sap of E.cottonii using HPLC. 


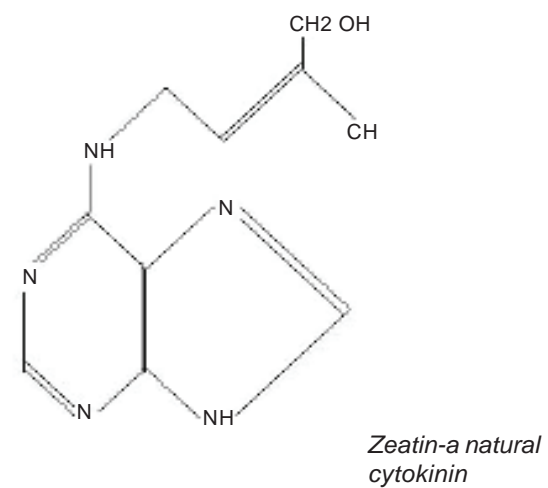

Gambar 6. Struktur molekuler zeatin.

Figure 6. Molecular stucture of zeatin (Anon., 2008).

selain itu sitokinin juga menunda penuaan daun, bunga dan buah dengan cara mengontrol dengan baik proses kemunduran yang menyebabkan kematian sel-sel tanaman (Lestari, 2004).

Efek menguntungkan dari penggunaan ekstrak rumput laut terhadap tanaman merupakan kombinasi hasil dari beberapa faktor yang bekerja secara sinergi dan pada jumlah konsentrasi penggunaan yang berbeda, meskipun sampai saat ini proses kerjanya masih belum diketahui secara pasti (Fornes et al., 2002). Penggunaan ekstrak rumput laut kini semakin populer. Hal ini disebabkan oleh potensi penggunaannya untuk pertanian organik dan berkelanjutan, khususnya untuk pertanian tadah hujan, yaitu sebagai solusi untuk menghindari pemakaian pupuk yang berlebihan dan untuk meningkatkan penyerapan mineral (Russo \& Beryln, 1990). Tidak seperti halnya pupuk kimia, ekstrak yang terbuat dari rumput laut dapat terdegradasi secara alami, tidak beracun, tidak mengkontaminasi, dan aman terhadap manusia dan hewan (Dhargalkar \& Pereira, 2005). Hasil analisis HPT terhadap sap E. cottonii menunjukkan bahwa senyawa giberelin merupakan senyawa HPT dengan kandungan terbesar di antara senyawa sitokinin dan auksin.
Pemanfaatan sisa padatan rumput laut yang telah diekstrak sap-nya

\section{Kualitas ATC}

Berikut adalah hasil uji kualitas kekuatan gel ATC yang dihasilkan dari pemanfaatan sisa padatan rumput laut yang telah diambil sap-nya (Tabel 1).

Menurunnya kekuatan gel ATC yang dihasilkan dari sisa ampas rumput laut yang telah diambil cairannya diduga karena ikut keluarnya karaginan dari sel bersamaan dengan sap pada saat pemerasan sehingga menurunkan nilai kekuatan gelnya. Selain itu, proses penghancuran dan pemerasan rumput laut juga mengakibatkan ikut keluarnya mineral-mineral terlarut bersamaan dengan sap rumput laut sehingga menurunkan kualitas gel ATC yang dihasilkan. Beberapa mineral atau ion logam sangat mempengaruhi dalam pembentukan gel kappa karaginan, seperti ion $\mathrm{K}, \mathrm{Ca}, \mathrm{Mg}$, dan $\mathrm{Na}$ yang dapat meningkatkan kekuatan gel (Zabik \& Aldrich, 1968).

Oleh karena itu, untuk mendapatkan sisa padatan yang masih dapat digunakan sebagai bahan baku ATC dengan kualitas baik, perlu dilakukan pengeluaran sap rumput laut dengan teknik berbeda, seperti dengan

Tabel 1. Kekuatan gel ATC hasil pemanfaatan sisa padatan rumput laut

Table 1. Gel strength of the ATC produced from sap extracted seaweed

\begin{tabular}{lcc}
\hline \multicolumn{1}{c}{ Bahan Baku ATCIATC Raw Material } & $\begin{array}{c}\text { Water Gel Strength } \\
\left(\mathbf{g} / \mathbf{c m}^{\mathbf{2}}\right)\end{array}$ & $\begin{array}{c}\mathrm{KCl} \text { Gel Strength } \\
\left(\mathbf{g / \mathbf { c m } ^ { 2 }}\right)\end{array}$ \\
\hline $\begin{array}{l}\text { Rumput laut yang telah diekstrak } \\
\text { cairannya/Sap extracted seaweed }\end{array}$ & 90 & 284 \\
$\begin{array}{l}\text { Rumput laut kontrol/Control (unextracted } \\
\text { seaweed) }\end{array}$ & 220 & 600 \\
\hline
\end{tabular}


cara pengepresan talus rumput laut sampai dengan tekanan tertentu yang tidak merusak atau menghilangkan karaginan dalam talus rumput laut.

\section{KESIMPULAN}

Analisis ekstrak cairan (sap) rumput laut E.cottonii dengan menggunakan HPLC didapatkan hasil positif mengandung hormon pemacu tumbuh (HPT) tanaman yaitu giberelin, auksin dan sitokinin. Secara umum, dibandingkan dengan HPT yang terdapat dalam produk pupuk organik rumput laut komersial, ekstrak cairan E.cottonii menunjukkan jumlah kandungan lebih tinggi. Dengan demikian rumput laut E.cottonii memiliki potensi untuk dikembangkan menjadi bahan pupuk organik cair, yaitu diaplikasikan sebagai pemacu pertumbuhan tanaman. Namun demikian, pemanfaatan rumput laut sisa ekstraksi sap untuk dijadikan alkali treated cottonii (ATC) masih menghasilkan kualitas ATC yang rendah.

\section{DAFTAR PUSTAKA}

Abe, H., Uchiyama, M., and Sato, R. 1972. Isolation and identification of native auxins in marine algae. Agric Biol Chem. 36: 2259-2260.

Abe, H., Uchiyama, M., and Sato, R. 1974. Isolation of phenylacetic acid and its p-hydroxy derivative as auxin-like substances from Undaria pinnatida. Agr. Biol. Chem. 38: 897-898.

Anonymous. 2008. http://www.rocw.raifondation.org/ biotechnology/Btechbiotech /lifescience-ii/lecturenotes/lecture-02.pdf. Diakses pada tanggal 13 Oktober 2008.

Beckett, R.P. and Van Staden, J. 1991. The effect of seaweed concentrate on the yield of salinity stress wheat. Acta Physiol. Plant. 13: 87-90.

Bey, Y., Syafii, W., dan Ngatifah, N. 2005. Pengaruh pemberian giberelin pada media vacint dan went terhadap perkecambahan biji anggrek bulan (Phalaenopsis amabilis BL) secara in vitro. Jurnal Biogenesis. 1(2): 57-61.

Brenner, M.I. 1981. Modern methods for plant growth substances analysis. Ann. Rev. Plant. Physiol. 32: 511-538.

Chapman, V.J. and Chapman D.J. 1980. Seaweed and Their Uses, $3^{r d}$ ed. Chapman \& Hall Ltd., London. $327 \mathrm{pp}$.

Crouch, I. J. and Staden, V. 1992. Identification of auxins in a commercial seaweed concentrate. J. Plant Physiol. 139: 590-594.

Crouch, I.J. and Staden, V. 1993. Evidence for the presence of plant growth regulators in commercial seaweed products. Plant Growth Regulation. 13(1): 21-29.

Dhargalkar, V.K. and Pereira, N., 2005. Seaweed: promising plant of the millennium. Science and Culture. 71: 60-66.
Fornes, F., Sanchez P.M., Guadiola, J.L. 2002. Effect of a seaweed extract on the productivity of 'de Nules' Clementine mandarin and navelina orange. Botanica Marina. 45: 486-489.

Gardner, F.P., Pearce, R.B., dan Mitchell R.L. 1991. Fisiologi Tanaman Budidaya. Penerjemah Susilo, H dan Pendamping Subiyanto. Cetakan Pertama. Penerbit Universitas Indonesia Press, Jakarta.

Han, L.J. 2006. The auxin concentration in sixteen Chinese marine algae. Chinese Journal of Oceanology and Limnology. 24(3): 329-332.

Jacobs, W.P., Falkenstein, K., and Hamilton, R.H. 1985. Nature and amount of auxin in algae : IAA from extracts of Caulerpa paspaloides (Siphonales). PI Physiol. 78: 844-848.

Kubo, I. 1989. Effect of a Marine Algal Constituent on the Growth of Lettuce and Rice Seedlings. Pure \& Appl. Chem. 3(61): 373-375.

Lestari, R.P. 2004. Peranan Zat Pengatur Tumbuh (ZPT) dalam Pertumbuhan dan perkembangan Tumbuhan. http://digilib.bi.itb.ac.id/go.php?id=jbptitbbi-gdl-s12004-ratihpujil-383. Diakses pada tanggal 6 Juni 2006.

Lin, D.D., Feng, P., Li, S., Shun, Z.J., Tong, L.X., and Geng, F.X. 1996. Identification cytokinin in a green algae extract. Chin. J. Oceanol. Limnol. 12(2): 160-164.

Linskens, H.F., and Jackson, J.F. 1987. High Performance Liquid Chromatography in Plant Sciences. Springer-Verlag. London. 241 pp.

Marine Colloid FMC. 1978. Raw Material Test Laboratory Standard Practice. Marine Colloids. Div. Corp. Springfield. New Jersey, USA. 53 pp.

Mooney, P.A. and Van Staden, J. 1985. Effect of seaweed concentrate on the growth of wheat under condition of water fern. S. Afr. J. Sci. 8: 632-633.

Mooney, P.A. and Van Staden, J. 1984․ Algae and Cytokinin. J. Plant. Physiol. 123: 1-21.

Mooney, P.A. and Van Staden, J. 1984 ${ }^{\mathrm{b}}$. Seasonal Changes and in the Level of endogeneous cytokinin in Sargassum heterophylum (Phaeophyceae). Bot. Mar. 27: 437-442.

Padhi, S.B. and Swain, P.K. 2006. Effective Role of Microorganism and Seaweed as Biofertilizer in Organic Farming for a Sustainable Environment. http://wgbis.ces.iisc.rnet.in/energy/lake2006/ programme/programme/proceedings/ fullpaper_pdfs/Sailabala\%20Padhi.pdf. Diakses pada tanggal 13 Oktober 2008.

Prithiviraj, B. 2009. Seaweed extracts as biostimulants of plant growth and development. J. Plant Growth Regul. 28: 386-399

Russo, R.O. and Beryln, G.P. 1990. The use of organic biostimulants to help low inputs. Journal of Sustainable Agriculture. 1: 9-42.

Schiewer, U. and Libbert, E. 1965. Indoleacetamide-an intermediate in the formation of indole acetic acid from indoleacetonitrile in the alga Furcellaria. Planta. 66: 377-380.

Sedayu, B.B., Basmal, J., and Melanie, S. 2011. Uji pengeringan rumput laut $(E$. Cottonii) menggunakan 
model alat pengering tipe $\mathrm{V}$ dengan menggunakan sumber panas gas elpiji. Prosiding Seminar Nasional Perikanan UGM 2011. 32 p.

Sekar, R., Thangaraju, N., and Rangasamy, R. 1995. Effect of seawed fertilizer from Ulva lactuca $L$. on Vigna Unguiculata L. (Walp) Phycos. 34: 49-53.

Sivasankari, S., Venkatesalu, V., Anantharaj, M., and Chandrasekaran, M. 2006. Bioresource Technology. (97): 1745-1751.

Smith, F.B.C. and Van Staden, J. 1984. The effect of seaweed concentrate and fertilizer on growth and endogenous cytokinin content of Phaseolus vulsaris. South African Journal of Botany. 3: 375-379.

Standerson, K.J., Jameson, P.E., and Zabkiewiez, J.A. 1987. Auxin in a seaweed extract: Identification and quantization of indole-3-acetic acid by gas chromatography-mass spectrometry. J. Plant Physiol. 129: 363-367.

Sumera, F.C. and Cajipe, G.J.B. 1981. Extraction and partial characterization of auxin-like substances from Sargassum polycystum. C. Ag. Bot Mar. 24: 157-163.
Taiz, L. and Zeiger, E. 1991. Cytokinins. In Taiz, L. and Zeiger, E. Benjamin/Cummings (eds.). Plant Physiology. Redwood City, CA. p. 452-472.

Thirmann, K.V. and Scoog, F. 1940. The extraction of auxin from plant tissues. American Journal Botany. 27: 951-960.

Van Overbeek, J. 1940. Auxin in marine algae. PI Physiol Lancaster. 15: 291-299

Williams, D.C., Brain, K.R., Blunden, G., Wildgoose, P.B. and Jewers, K. 1976. Plant growth regulatory substances in commercial seaweed extracts. Proc. Int Seaweed Symp. 8: 59-63.

Wu, T.W. and Lin, C.H. 2000. Analysis of cytokinin activity in commercial aqueous seaweed extract. Gartenbauwissenschaft. 65(4): 170-173.

Zabik, M.E. and Aldrich, P.J. 1968. Gel strength of kappacarrageenan as affected by cations. Journal of Food Science. 33(4): 371-377.

Zahid, P.B. 1999. Preparation of organik fertilizer from seaweed and its effect on the growth of some vegetable and ornamental plants. Pakistan Journal of Biological Sciences. 2(4): 1274-1277. 